\title{
Effect of grape pomace rich in flavonoids and antioxidants on production parameters in dairy production
}

\author{
B. Nielsen ${ }^{1}$ and H. Hansen ${ }^{2}$ \\ ${ }^{I}$ Nor-Feed A/S, Kanalholmen 2, 2650 Hvidovre, Denmark \\ ${ }^{2}$ Department of Large Animal Sciences, The Royal Veterinary and Agricultural University \\ Groennegaardsvej 2, 1870 Frederiksberg C, Denmark
}

\begin{abstract}
The objectives of this study were to examine the effect of grape pomace on milk yield, milk composition and cell counts in dairy cattle. Danish Red Holstein dairy cows were allocated to either group CON $(n=103)$ or group CAB $(n=108)$ that was supplemented with 4.5 g grape pomace per cow per day. Significant differences in milk yield were not observable, but group CAB did show a tendency towards increased milk yield at the level of $0.4 \mathrm{~kg} / \mathrm{cow} /$ day $(\mathrm{P}=0.1)$. No effects of grape pomace on cell counts were seen. It is concluded that inclusion of small amounts of grape pomace as a feed additive does not increase protein yield when added to a high protein diet to lactating cows.
\end{abstract}

KEY WORDS: natural additives, milk yield, polyphenolics, tannins, Vitis vinifera

\section{INTRODUCTION}

Grape pomace, a by-product from wine production from Vitis vinifera, consists of pressed skins, seeds and stems, and represents as much as $20 \%$ of the weight of grapes processed. Grape pomace contains phenolic compounds, primarily tannins, that play an important role in determining the colour, taste and body of wine (Bombardelli and Morazzoni, 1995).

Flavonoids are a broad class of polyphenolic compounds which are hypothesized to be important in wine-promoted vascular protection (SauraCalixto, 1998). Flavonoids are supposed to have pharmacological activities such as free radical scavenging, cancer protective, anti-inflammatory properties (Schubert et al., 1999) as well as antimicrobial and antioxidant activities (Saura-

\footnotetext{
${ }^{1}$ Corresponding author: e-mail: b.nielsen@norfeed.dk
} 
Calixto, 1998). Tannins from grape seed extracts were found to have a gastric protective activity by covering the stomach surface in rats (Saito et al., 1998).

Covering the rumen epithelium may prevent toxins from invading the blood with a resultant positive effect on health and production, particularly for lactating cows with a risk for acidosis and laminitis.

Condensed tannins form a complex with proteins thus reducing nitrogen availability to rumen microorganisms and increasing total supply of protein for intestinal absorption in ruminants (McSweeney et al., 2001). Furthermore the ability of form a complex with proteins may change the ruminal microbial population (Min et al., 2003).

Subclinical infections may reduce productivity, and bioactive additives may reduce these effects and may have positive effects on productivity (Min et al., 2003). The objective of this study was to examine the effects of grape pomace on milk yield, milk composition and somatic cell counts in dairy cattle.

\section{MATERIAL AND METHODS}

\section{Design and treatments}

The experiment was carried out on a private Danish farm in the autumn of 2003 with Danish Red Holstein dairy cows. The experiment started on 12 September and continued for 75 days. Two hundred and nine dairy cows (158 \pm 105 days of lactation, $2.1 \pm 1.3$ lactation number, $26.0 \pm 7.0 \mathrm{~kg} / \mathrm{milk} / \mathrm{cow} /$ day) were allocated to 2 treatments. The treatment groups were balanced for milk yield and days after start of lactation. Group CAB was supplemented with grape pomace and group CON was fed with same basal diet without the additive. As a source of grape pomace the feed additive Cabanin CS Powder from Nor-Feed A/S was chosen, with a total supplementation of mean $4.5 \mathrm{~g}$ grape pomace per cow per day added to the feed ration as topdressing on the TMR.

\section{Samplings, recordings and analysis}

Milk yield, protein and fat content were recorded daily by a milking robot, and mean values were calculated every week. Values for somatic cell counts were measured once a month. Feed samples were taken once of the individual feedstuffs and analysed for ash, crude protein and digestibility of organic matter (OMD) (Table 1). OMD in vivo was calculated by NIR-analysis. NIR was calibrated against in vitro digestibility (Tilley and Terry, 1963) and corrected to sheep digestibility (Møller et al., 1989).

\section{Statistical analyses}

The effect of the feed additive on milk yield, somatic cell counts, fat and protein percentage in the milk was analysed by an analysis of variance with treatment and 
parity as the main factors and days in lactation and milk yield before start of the experiment as covariate. Estimates were performed as lsmeans. All statistical analyses were done using SAS (SAS Institute Inc., 1999).

\section{RESULTS}

Table 1. Ingredient and chemical composition of the basal diet (total mixed ration), $\%$ of DM

\begin{tabular}{lc}
\hline Ingredient, \% & 6.8 \\
ryegrass and barley hay & $26.4 / 21.5$ \\
whole crop barley/maize silage & $14.4 / 2.7$ \\
soyabean/sunflower meal & 2.3 \\
rapeseed cake & 5.3 \\
lucerne meal & 4.9 \\
sugar beet pulp & 3.6 \\
molasses & 7.4 \\
peas and maize & 0.6 \\
mineral mix & 4.1 \\
others & \\
& \\
Chemical composition & 42.3 \\
dry matter, \% & 18.3 \\
crude protein, \% DM & 6.4 \\
ash, \% of DM & 79.7 \\
in vivo OMD, \% & 7.8 \\
Ca, g/kg DM & 4.4 \\
P, g/kg DM & \\
\hline
\end{tabular}

Table 2. Effect of grape pomace on milk yield and milk parameters and cell counts

\begin{tabular}{|c|c|c|c|c|c|c|}
\hline & \multirow{2}{*}{$\begin{array}{c}\text { Group CON } \\
\mathrm{n}=103\end{array}$} & \multirow{2}{*}{$\begin{array}{c}\text { Group CAB } \\
\mathrm{n}=108\end{array}$} & \multicolumn{4}{|c|}{ Effect of } \\
\hline & & & $\begin{array}{l}\text { days in } \\
\text { lactation }\end{array}$ & parity & $\begin{array}{l}\text { milk yield } \\
\text { at start }\end{array}$ & $\begin{array}{l}\text { treat- } \\
\text { ment }\end{array}$ \\
\hline $\begin{array}{l}\text { Milk yield, } \\
\text { kg/cow/day }\end{array}$ & $24.5 \pm 6.9$ & $24.9 \pm 7.2$ & $* * *$ & $* * *$ & $* * *$ & NS \\
\hline $\begin{array}{l}\text { Protein } \\
\text { kg total } \\
\%\end{array}$ & $\begin{array}{l}0.91 \pm 0.22 \\
3.76 \pm 0.45\end{array}$ & $\begin{array}{l}0.92 \pm 0.23 \\
3.72 \pm 0.41\end{array}$ & $\begin{array}{l}* * * \\
* * *\end{array}$ & $\begin{array}{l}* * * \\
\text { NS }\end{array}$ & $\begin{array}{l}* * * \\
\text { NS }\end{array}$ & $\begin{array}{c}\text { NS } \\
*\end{array}$ \\
\hline $\begin{array}{l}\text { Fat } \\
\qquad \mathrm{kg} \text { total } \\
\quad \%\end{array}$ & $\begin{array}{l}1.095 \pm 0.34 \\
4.51 \pm 0.99\end{array}$ & $\begin{array}{c}1.103 \pm 0.34 \\
4.48 \pm 0.93\end{array}$ & $\begin{array}{l}* * * \\
\text { NS }\end{array}$ & $\begin{array}{l}* * * \\
* * *\end{array}$ & $\begin{array}{l}* * * \\
\text { NS }\end{array}$ & $\begin{array}{l}\text { NS } \\
\text { NS }\end{array}$ \\
\hline Cell counts/1000 & $247 \pm 412$ & $233 \pm 435$ & NS & $* * *$ & NS & NS \\
\hline
\end{tabular}

No significant differences in milk yield could be observed at the $\mathrm{P}=0.05$ level, although the $\mathrm{CAB}$ group had an increased milk yield of $0.4 \mathrm{~kg} / \mathrm{cow} /$ day $(\mathrm{P}=0.1)$ (Table 2). Only the protein percent in milk was significantly different between 
the treatments, but the difference was small (Table 2). Limited effects of the feed additive on somatic cell counts were seen.

\section{DISCUSSION}

The hypothesis of improved protein utilization due to reduced ruminal protein degradation with effect on protein content in milk could not be confirmed in the present trial. The protein content in the total diet met the requirements of the lactating cows, and a possible improved protein utilization may not be seen in increased protein yield but rather in total improved energy utilization that might be an explanation of the tendency of increased milk yield. Increased milk yield in cows and ewes with high tannin feed ration was also mentioned by Min et al. (2003). The antioxidant capacity of grape pomace may have effects on somatic cell counts and reproduction. Additionally tannins were found to have toxic effects on Staphylococcus aureus (Scalbert, 1991). In the present trial somatic cell counts were lowest in the trial group but no significant effect was found. The feed additive Cabanin CS Powder also contains the bioactive elements citrus and chestnut that may have direct or synergistic effects.

\section{CONCLUSIONS}

It is concluded that inclusion of small amounts of grape pomace as a feed additive does not increase protein yield when added to a high protein diet for lactating cows. Addition of grape pomace resulted in a limited increase in milk yield. More knowledge is needed regarding the effect of grape pomace on udder health and digestion related diseases.

\section{REFERENCES}

Bombardelli E., Morazzoni P., 1995. Vitis vinifera L. Fitoterapia 16, 291-317

McSweeney C.S., Palmer B., McNeill D.M., Krause D.O., 2001. Microbial interactions with tannins: nutritional consequences for ruminants. Anim. Feed Sci. Tech. 91, 83-93

Min B.R., Barry T.N., Attwood G.T., McNabb W.C., 2003. The effect of condensed tannins on the nutrition and health of ruminants fed fresh temperate forages: a review. Anim. Feed Sci. Tech. 106, 3-19

Møller E., Andersen P.E., Witt N., 1989. En sammenligning af in vitro opløselighed og in vivo fordøjelighed af organisk stof i grovfoder. 13. Beretning fra Fællesudvalget for Statens Planteavls- og Husdyrbrugsforsøg, pp. 23

Saito M., Hosoyama H., Ariga T., Kataoka S., Yamaji N., 1998. Antiulcer activity of grape seeds extract and procyanidins. J. Agr. Food Chem. 46, 1460-1464

SAS, 1999. User's Guide, version 8. SAS Institute Inc., Cary, NC

Sauro-Calixto F., 1998. Antioxidant dietary fiber product: A new concept and a potential food ingredient. J. Agr. Food Chem. 46, 4303-4306

Scalbert A., 1991. Antimicrobial properties of tannins. Phytochemistry 30, 3875-3883

Schubert S.Y., Lansky E.P., 1999. Antioxidant and eicosanoid enzyme inhibition properties of pomegrate seed oil and fermented juice flavonoids. J. Ethnopharmacol. 66, 11-17

Tilley J.M., Terry R.A., 1963. A two-stage technique for the in vitro digestion for forage crops. J. Brit. Grassl. Soc. 18, 104-110 